\title{
Kronika \\ Katedry Nauk Historycznoprawnych Wydziału Prawa Uniwersytetu w Białymstoku (rok 2007)
}

\section{Publikacje}

Owocem aktywności naukowej pracowników Katedry w roku 2007 jest kilkanaście publikacji naukowych. Na łamach "Czasopisma Prawno-Historycznego" zostały opublikowane artykuły Adama Lityńskiego (O pojmowaniu praworządności socjalistycznej w Polsce Ludowej, CPH 2007, z. 1), Marcina Łysko (Kolegia karno-administracyjne $w$ walce $z$ Kościołem katolickim w Polsce (1956-1970), CPH 2007, z.1) i Karola Kuźmicza (Filozofia prawa Edmunda Krzymuskiego, CPH 2007, z. 2). Piotr Fiedorczyk jest autorem publikacji w języku angielskim Family Law in $20^{\text {th }}$ Century Poland: between Soviet Patterns and European Legal Tradition, która ukazała się w pracy zbiorowej: Family Law: Balancing Interests and Pursuing Priorities, red. L. D. Wardle i C. S. Williams, Buffalo-New York 2007.

W ramach materiałów pokonferncyjnych zostały opublikowane referaty następujących pracowników Katedry:

- Adama Lityńskiego (Dwie wielkie transformacje prawa sadowego w Polsce XX wieku. Koncepcje i ich realizacja, [w:] W pięćsetlecie konstytucji Nihil novi. $Z$ dziejów stanowienia prawa w Polsce, red. A. Ajnenkiel, Warszawa 2006. Oświeceniowe korzenie dzisiejszych zasad prawa karnego i cywilnego, [w:] Zasady prawa. Materiały konferencyjne, red. C. Martysz, A. Matan, Z. Tobor, Bydgoszcz-Katowice 2007);

- Piotra Fiedorczyka, Nowelizacje prawa rodzinnego w Polsce po 1989 r. ze szczególnym uwzględnieniem stosunków majątkowych między małżonkami, [w:] Małżeństwo - etyka - ekonomia, red. E. Ozorowski i R. Cz. Horodeński, Białystok 2007. Uwagi o zasadach prowadzenia działalności gospodarczej w prawie II Rzeczypospolitej, [w:] Ekonomiczne aspekty państwa demokratycznego, red. S. Oliwniak, Białystok 2007);

- Piotra Kołodko (Chłosta jako dodatkowy środek karny zaostrzajacy dolegliwość kary właściwej, [w:] Salus rei publicae suprema lex. Ochrona interesów państwa w starożytnej Grecji i Rzymie, pod red. A. Dębińskiego, H. Kowalskiego i M. Kuryłowicza, Lublin 2007). 
Adam Lityński opublikował w 2007 roku na łamach wydawanych przez Uniwersytet Śląski zeszytów naukowych „Z dziejów prawa” następujące artykuły:

- O praworządności ,ludowej” w Polsce 1944-1956 teoretycznych uwag kilka, „Z dziejów prawa”, cz. 8, red. A. Lityński, M. Mikołajczyk, W. Organiściak;

- O ustanowieniu i upadku tzw. Kodeksu wojskowego Polskich Sił Zbrojnych w ZSRR, „Z dziejów prawa”, cz. 8, red. A. Lityński, M. Mikołajczyk, W. Organiściak;

- Wyrok na „kodeks” PSZ w ZSRR, „Z dziejów prawa”, cz. 8, red. A. Lityński, M. Mikołajczyk, W. Organiściak.

- Stanisław Płaza (1927-2006) widziany z Katowic [nekrolog], „Z dziejów prawa”, cz. 8, red. A. Lityński, M. Mikołajczyk, W. Organiściak.

W zeszytach naukowych „Miscellanea Iuridica” wydawanych przez Śląskie Wydawnictwa Naukowe we współpracy z Wyższą Szkołą Zarządzania i Nauk Społecznych w Tychach Adam Lityński zamieścił artykuł pt. Ku własnemu prawu we własnym państwie. Tworzenie prawa sądowego w II Rzeczypospolitej („,Miscellanea Iuridica”, t. 9, red. A. Lityński i A. Drogoń).

Karol Kuźmicz publikował w wydawanych przez Wydział Prawa Uniwersytetu w Białymstoku zeszytach naukowych (Odzwierciedlenie założeń kantowskiej filozofii w pogladach filozoficznoprawnych Antoniego Peretiatkowicza, [w:] Wybrane problemy prawa krajowego i europejskiego, Białystok 2007) oraz $\mathrm{w}$ pracy zbiorowej - Ideowość w polityce (Od ideowości do szaleństwa, [w:] Ideowość w polityce, pod red. M. Szyszkowskiej, Warszawa 2007).

W roku 2007 ukazał się kolejny, piaty już tom zeszytów katedralnych „Miscellanea Historico-Iuridica”; obecnie trwają prace nad kolejnym zeszytem.

\section{UDZIAE W KONFERENCJACH NAUKOWYCH}

Pracownicy Katedry brali udział w krajowych i zagranicznych konferencjach naukowych. W międzynarodowej konferencji romanistów w Bari uczestniczył Krzysztof Szczygielski, występując z referatem Il culto della memoria dei defunti come diritto soggetivo e la sua tutela nellordinamento giuridico polacco. We wrześniu 2007 r. Krzysztof Szczygielski prowadził w języku angielskim wykłady na Wydziale Prawa Università degli Studi di Bari (Włochy) w ramach programu Life Long Learning Programme-Erasmus. Temat wykładów: Cult of remembrance after deceased person as a personal interests and its protection in Polish law. Piotr Niczyporuk uczestniczył w konferencji romanistów „IX Colloquio dei romanisti dell' Europa Centro-Orientale e dell'Asia”, która odbyła się w Craiova (Rumunia) 
na przełomie października i listopada 2007. Wystąpił tam z referatem Nummularii как банкири (Nummularii на страже качества монет в древнем Риме).

W polsko-włoskiej konferencji naukowej „La persona e la famiglia nel diritto romano e nelle radici dei diritti dell'Europa" (Osoba i rodzina w prawie rzymskim i w tradycji prawa europejskiego) zorganizowanej przez Wydział Prawa Wyższej Szkoły Handlu i Prawa im. Ryszarda Łazarskiego w Warszawie w dniach 29-30 listopada 2007 r. brali udział Piotr Fiedorczyk i Krzysztof Szczygielski. Piotr Fiedorczyk wystąpił z referatem Recepcje obcych rozwiązań prawnych $w$ polskim prawie rodzinnym, natomiast Krzysztof Szczygielski zaprezentował Znaczenie powinowactwa $w$ prawie rzymskim $i$ współczesnych ustawodawstwach cywilnych.

W konferencji poświęconej ochronie interesów państwa w starożytnej Grecji i Rzymie - „Salus rei publicae suprema lex”, która odbyła się w Lublinie w maju 2007 r., uczestniczył Piotr Kołodko. Wystąpił tam z referatem Chłosta jako dodatkowy środek karny zaostrzający dolegliwość kary właściwej. Podczas zorganizowanej przez Towarzystwo Biblioteki Słuchaczów Prawa UJ w Krakowie w marcu 2007 r. konferencji „Prawo blisko człowieka - z dziejów prawa spadkowego i rodzinnego" Piotr Fiedorczyk wygłosił referat zatytułowany Wspólne cechy prawa rodzinnego w europejskich państwach komunistycznych. W IV Zjeździe Katedr i Wykładowców Prawa Wyznaniowego w Białymstoku we wrześniu 2007 r. brał udział Marcin Łysko, występując z referatem Przepisy wyznaniowe w konstytucjach II Rzeczypospolitej.

Adam Lityński przewodniczył obradom konferencji „Ruch współzawodnictwa socjalistycznego w życiu gospodarczym, społeczno-politycznym i propagandzie Polski Ludowej”. Zorganizowana przez katowicki oddział Instytutu Pamięci Narodowej konferencja odbyła się w dniach 15-16 listopada 2007 r. na Wydziale Prawa Uniwersytetu Śląskiego. 